\title{
OPEN Developmental stages of peach, plum, and apple fruit influence development and fecundity of Grapholita molesta (Lepidoptera: Tortricidae)
}

\begin{abstract}
Souvic Sarker, Young Ha Woo \& Un Taek Lim
Host plant attributes are essential factors determining the population dynamics of herbivorous insects. The developmental stage of host plants, in particular, may affect the biology of Grapholita molesta (Busck), a possibility that has rarely been examined. Here we assessed the effect of developmental stage of plum, peach, and apple fruits on the development and fecundity performance of $G$. molesta, along with an examination of the firmness and sugar content of the fruits. Among the fruits collected earliest (May 31), plum and apple were better food sources for $G$. molesta compared to peach in terms of development, reproduction, and life table parameters. However, despite the higher sugar content in peach, G. molesta larvae showed a lower rate of fruit penetration in peach, probably due to fruit firmness. In the later-collected fruit (June 25), both peach and apple were better than plum, as peach and apple were softer and had higher sugar content. Nevertheless, the penetration rate of larva was still low in peach probably due to pubescence on the fruit surface. Although the plum fruits in the later collection date were softer with higher sugar content, there was a negative impact on the development and reproduction because fruits started to liquefy earlier. In conclusion, the developmental stage of fruits with changes in fruit firmness or sugar content affected the development and reproduction of $G$. molesta, and apple would be the best food source.
\end{abstract}

The oriental fruit moth, Grapholita molesta (Busck) (Lepidoptera: Tortricidae), is a globally important insect pest $^{1}$. It is widespread across temperate and subtropical regions in Asia, Europe, the Americas, Africa, and Australia ${ }^{2,3}$, with a host range encompassing species in the Rosaceae, including most species of Prunus and Pyrus $^{2}$. The stone fruits, plum Prunus domestica L. and peach Prunus persica (L.) (Rosales: Rosaceae), are considered the primary hosts of G. molesta, whereas the pome fruits, pear Pyrus communis L. (Rosales: Rosaceae) and apple Malus domestica Borkh. (Rosales: Rosaceae), are considered secondary hosts ${ }^{2,4,5}$. The pest undergoes 3-6 generations per year depending on the location and temperature ${ }^{6-10}$.

Many invasive herbivores have a common characteristic of utilizing a broad range of host plants ${ }^{11,12}$. The population dynamics of herbivorous insects depend on the availability of suitable host plants ${ }^{13,14}$, and the phenology of host plants in turn influences the performance (such as development time, survival rate, and fecundity) of herbivorous insects ${ }^{15-17}$. Previous studies have showed that the phenology of host plants influences the seasonal dynamics of the stink bug Halyomorpha halys (Stål) ${ }^{18}$ and the survival or fitness of the tortricid moths Choristoneura rosaceana (Harris) ${ }^{19}$ and Choristoneura fumiferana (Clemens) ${ }^{20}$. Larvae of G. molesta feed at different sites on peaches and apples over the course of the growing season ${ }^{21}$, and Du et al. ${ }^{1}$ showed how phenological succession of peach and pear plants can influence the population dynamics of G. molesta.

The larval survival of G. molesta is better on shoots than on fruits in peach early in the season ${ }^{1,22}$, and thus $G$. molesta larvae infest shoots more frequently early in the growing season. Later in the growing season, G. molesta moths are attracted more to fruits than twigs ${ }^{23,24}$. The firmness of the fruit in the early season may influence larval survival ${ }^{17}$, while sugar content may also affect larval development ${ }^{25}$. Our previous study ${ }^{26}$ found that immature plum or apple fruits were better food sources than peach, although larval survival was found to be better in ripening peach fruits than in immature ones ${ }^{22}$. However, the underlying causes of those discrepancies are still 


\begin{tabular}{|l|l|l|l|l|l|l|}
\hline Fruit & Collected on & Egg (d) & Larva (d) & Prepupa (d) & Pupa (d) & Larva- pupa (d) \\
\hline \multirow{4}{*}{ Plum } & May $11^{\ddagger}$ & $3.13 \pm 0.06$ & $11.44 \pm 0.61 \mathrm{~b}^{\S}$ & $3.47 \pm 0.12 \mathrm{~b}$ & $7.67 \pm 0.43 \mathrm{~b}$ & $23.13 \pm 0.74 \mathrm{~b}$ \\
\cline { 2 - 7 } & May 31 & $3.17 \pm 0.07$ & $10.79 \pm 0.29 \mathrm{bA}^{\S \S}$ & $3.52 \pm 0.18 \mathrm{bC}$ & $9.11 \pm 0.42 \mathrm{bA}$ & $23.58 \pm 0.49 \mathrm{bA}$ \\
\cline { 2 - 7 } & June 11 & $3.20 \pm 0.07$ & $14.93 \pm 1.16 \mathrm{aA}$ & $4.69 \pm 0.33 \mathrm{aA}$ & $10.18 \pm 0.46 \mathrm{aA}$ & $29.55 \pm 1.03 \mathrm{aA}$ \\
\cline { 2 - 7 } & June 25 & $3.23 \pm 0.08$ & $13.93 \pm 0.22 \mathrm{aA}$ & $4.58 \pm 0.15 \mathrm{aA}$ & $10.80 \pm 0.42 \mathrm{aA}$ & $29.10 \pm 0.46 \mathrm{aA}$ \\
\hline \multirow{3}{*}{ Peach } & May 31 & $3.30 \pm 0.09$ & $9.13 \pm 0.40 \mathrm{aB}$ & $4.25 \pm 0.16 \mathrm{aA}$ & $9.29 \pm 1.25 \mathrm{aA}$ & $22.57 \pm 1.32 \mathrm{aAB}$ \\
\cline { 2 - 7 } & June 11 & $3.23 \pm 0.08$ & $8.82 \pm 0.35 \mathrm{aC}$ & $3.40 \pm 0.22 \mathrm{bB}$ & $9.44 \pm 0.29 \mathrm{aA}$ & $21.33 \pm 0.38 \mathrm{aC}$ \\
\cline { 2 - 7 } & June 25 & $3.27 \pm 0.08$ & $8.58 \pm 0.26 \mathrm{aC}$ & $3.41 \pm 0.15 \mathrm{bB}$ & $8.56 \pm 0.24 \mathrm{aB}$ & $20.33 \pm 0.33 \mathrm{aB}$ \\
\hline \multirow{3}{*}{ Apple } & May 31 & $3.20 \pm 0.07$ & $8.44 \pm 0.22 \mathrm{cB}$ & $3.13 \pm 0.10 \mathrm{bB}$ & $10.35 \pm 0.33 \mathrm{aA}$ & $21.74 \pm 0.38 \mathrm{cB}$ \\
\cline { 2 - 7 } & June 11 & $3.27 \pm 0.08$ & $10.64 \pm 0.49 \mathrm{bB}$ & $3.86 \pm 0.13 \mathrm{aAB}$ & $10.24 \pm 0.29 \mathrm{aA}$ & $24.24 \pm 0.60 \mathrm{bB}$ \\
\cline { 2 - 7 } & June 25 & $3.23 \pm 0.08$ & $12.68 \pm 0.27 \mathrm{aB}$ & $4.05 \pm 0.20 \mathrm{aAB}$ & $11.59 \pm 0.56 \mathrm{aA}$ & $28.06 \pm 0.66 \mathrm{aA}$ \\
\hline
\end{tabular}

Table 1. Durations $(\mathrm{d} \pm \mathrm{SE})$ of each life stage of oriental fruit moth, Grapholita molesta, reared in plum, peach, and apple fruits collected at various times of the growing season. ${ }^{\ddagger}$ Excluded in two-way ANOVA. ${ }^{8}$ Means followed by different lower case letter are significantly different among collection dates within a fruit species. ${ }^{\S \varsigma}$ Means followed by different upper case letter are significantly different among host fruits in each collection date.

unknown. We hypothesize that firmness and sugar content may affect the development and reproduction of $G$. molesta, and to test this, we investigated the effect of the developmental stages of plum, peach, and apple fruit on the development, reproduction, and life table parameters of G. molesta, while also examining fruit firmness and sugar content.

\section{Results}

Stage development and survival rates. Egg duration of $G$. molesta was not affected by fruit species $(F=0.54, d f=2,261, P=0.581)$, by collection date $(F=0.06, d f=2,261, P=0.941)$, or by fruit species by collection date interaction $(F=0.24, d f=4,261, P=0.914)$ (Table 1$)$. Durations of other life stages were all significantly affected by fruit species (larva $F=28.16, d f=2,144, P<0.001$; prepupa $F=4.38, d f=2,133, P=0.014$; pupa $F=8.76, d f=2,113, P<0.001$; larva-pupa $F=22.92, d f=2,113, P<0.001$ ), by collection date (larva $F=17.43$, $d f=2,144, P<0.001$; prepupa $F=7.73, d f=2,133, P<0.001$; larva-pupa $F=11.59, d f=2,113, P<0.001)$ except pupa $(F=1.99, d f=2,113, P=0.142)$, or by fruit species by collection date interaction (larva $F=30.59, d f=4,144$, $P<0.001$; prepupa $F=5.15, d f=4,133, P<0.001$; pupa $F=8.41, d f=4,113, P<0.001$; larva-pupa $F=16.12, d f=4$, $113, P<0.001)$.

Duration of the larval stage became longer in plum and apple as fruit collection date, but it showed opposite trend in peach. Among later-collected fruits (June 25), duration of the larval stage was shortest in peach.

Prepupal duration showed similar pattern as in larval duration. Pupal duration became longer as collection date in plum fruits, but no such trend was found in either peach or apple. In comparison on each collection date, no significance was found among fruits except June 25 when peach showed shortest pupal duration.

The total period from of larva plus pupa was also shortest when insects were reared on peach fruits collected on June $25(20.33 \mathrm{~d})$ compared to those reared on either plum or apple fruits collected on same date.

Hatching rate of eggs were not affected by fruit species $(F=3.44, d f=2,4, P=0.101)$, by collection date $(F=1.03, d f=2,4, P=0.413)$, or by fruit species by collection date interaction $(F=3.50, d f=4,4, P=0.126)$ (Table 2). The fruit penetration rate of first instars was not statistically different within each fruit developmental stages $(F=0.25, d f=2,4, P=0.789)$ or by fruit species by collection date interaction $(F=4.50, d f=4,4, P=0.087)$, but was significantly different between fruit species $(F=6.39, d f=2,4, P=0.033)$. For example, the fruit penetration rate was lowest in peach $(0.40)$, compared to plum $(0.87)$ or apple $(0.83)$ collected on May $31\left(\chi^{2}=19.37\right.$, $d f=2, P=0.009)$. The fruit exiting rate was also affected by fruit species $(F=5.35, d f=2,4, P=0.046)$ but not by collection date $(F=0.35, d f=2,4, P=0.720)$, or by fruit species by collection date interaction $(F=3.50, d f=4,4$, $P=0.126)$. The fruit exiting rate of mature larva was similar within each fruit species for all fruit collection dates. Among fruit species, the fruit exiting rate was highest in apple than peach on May $31\left(\chi^{2}=10.63, d f=2, P=0.005\right)$. Pupation rate and emergence rate were not affected by fruit species (pupation rate $F=1.37, d f=2,4, P=0.324$; emergence rate $F=0.17, d f=2,4, P=0.848$ ), by collection date (pupation rate $F=1.07, d f=2,4, P=0.401$; emergence rate $F=1.04, d f=2,4, P=0.401$ ), or by fruit species by collection date interaction (pupation rate $F=0.13$, $d f=4,4, P=0.966$; emergence rate $F=0.15, d f=4,4, P=0.951)$. Total immature survival rate was affected by fruit species $(F=9.60, d f=2,4, P=0.014)$ or by fruit species by collection date interaction $(F=15.50, d f=4,4$, $P=0.011)$, but not by collection date $(F=0.15, d f=2,4, P=0.864)$. In general, the total immature survival rate was highest in apple collected on May 31 compared to peach $\left(\chi^{2}=26.12, d f=2, P<0.001\right)$.

Within individual fruit species, larval survival rate was similar across collection dates $(F=0.25, d f=2,4$, $P=0.789)$, but there were significant differences among fruit species $(F=9.03, d f=2,4, P=0.015)$, or by fruit species by collection date interaction $(F=15.50, d f=4,4, P=0.011)$. For example, larval survival rate in apple was significantly higher than other fruits, and this was true for all developmental periods $(0.83,0.73$, and 0.73$)$ compared to peach $(0.27,0.37$, and 0.40$)$ (Table 2$)$. No significant differences in larval survival rate were observed between apple and plum in all developmental stages. 


\begin{tabular}{|c|c|c|c|c|c|c|c|c|}
\hline Fruit & Collected on & Hatching rate of egg & $\begin{array}{l}\text { Fruit penetration } \\
\text { rate of first instar } \\
\text { larva }\end{array}$ & $\begin{array}{l}\text { Fruit exiting rate of } \\
\text { mature larva }\end{array}$ & Larval survival rate & Pupation rate & Emergence rate & $\begin{array}{l}\text { Total immature } \\
\text { survival rate }\end{array}$ \\
\hline \multirow{4}{*}{ Plum } & May $11^{\ddagger}$ & $0.92(619 / 675)$ & $0.83(25 / 30) \mathrm{a}^{\S}$ & $0.72(18 / 25) \mathrm{a}$ & $0.60(18 / 30) \mathrm{ab}$ & $0.94(17 / 18)$ & $0.88(15 / 17)$ & $0.50(15 / 30) \mathrm{a}$ \\
\hline & May 31 & $0.93(769 / 823)$ & $0.87(26 / 30) \mathrm{aA}^{\S \S}$ & $0.92(24 / 26) \mathrm{aAB}$ & $0.80(24 / 30) \mathrm{aA}$ & $0.96(23 / 24)$ & $0.83(19 / 23)$ & $0.63(19 / 30) \mathrm{aA}$ \\
\hline & June 11 & $0.94(678 / 720)$ & $0.80(24 / 30) \mathrm{aA}$ & $0.63(15 / 24) \mathrm{aB}$ & $0.50(15 / 30) \mathrm{abAB}$ & $0.87(13 / 15)$ & $0.85(11 / 13)$ & $0.37(11 / 30) \mathrm{aA}$ \\
\hline & June 25 & $0.94(426 / 452)$ & $0.73(22 / 30) \mathrm{aAB}$ & $0.64(14 / 22) \mathrm{aA}$ & $0.47(14 / 30) \mathrm{bAB}$ & $0.86(12 / 14)$ & $0.83(10 / 12)$ & $0.33(10 / 30) \mathrm{aA}$ \\
\hline \multirow{3}{*}{ Peach } & May 31 & $0.95(331 / 349)$ & $0.40(12 / 30) \mathrm{aB}$ & $0.67(8 / 12) \mathrm{aB}$ & $0.27(8 / 30) \mathrm{aB}$ & $1.00(8 / 8)$ & $0.88(7 / 8)$ & $0.23(7 / 30) \mathrm{aB}$ \\
\hline & June 11 & $0.95(765 / 808)$ & $0.47(14 / 30) \mathrm{aB}$ & $0.79(11 / 14) \mathrm{aAB}$ & $0.37(11 / 30) \mathrm{aB}$ & $0.91(10 / 11)$ & $0.90(9 / 10)$ & $0.30(9 / 30) \mathrm{aA}$ \\
\hline & June 25 & $0.95(984 / 1033)$ & $0.50(15 / 30) \mathrm{aB}$ & $0.80(12 / 15) \mathrm{aA}$ & $0.40(12 / 30) \mathrm{aB}$ & $1.00(12 / 12)$ & $0.75(9 / 12)$ & $0.30(9 / 30) \mathrm{aA}$ \\
\hline \multirow{3}{*}{ Apple } & May 31 & $0.93(1274 / 1367)$ & $0.83(25 / 30) \mathrm{aA}$ & $1.00(25 / 25) \mathrm{aA}$ & $0.83(25 / 30) \mathrm{aA}$ & $0.92(23 / 25)$ & $1.00(23 / 23)$ & $0.77(23 / 30) \mathrm{aA}$ \\
\hline & June 11 & $0.95(814 / 861)$ & $0.77(23 / 30) \mathrm{aA}$ & $0.96(22 / 23) \mathrm{aA}$ & $0.73(22 / 30) \mathrm{aA}$ & $0.95(21 / 22)$ & $0.81(17 / 21)$ & $0.57(17 / 30) \mathrm{aA}$ \\
\hline & June 25 & $0.95(1337 / 1409)$ & $0.80(24 / 30) \mathrm{aA}$ & $0.92(22 / 24) \mathrm{aA}$ & $0.73(22 / 30) \mathrm{aA}$ & $0.91(20 / 22)$ & $0.85(17 / 20)$ & $0.57(17 / 30) \mathrm{aA}$ \\
\hline
\end{tabular}

Table 2. Survival rate of each life stage of oriental fruit, Grapholita molesta, moth reared in plum, peach, and apple fruits collected at various times of the growing season. ${ }^{\ddagger}$ Excluded in two-way ANOVA. ${ }^{\S}$ Means followed by different lower case letter are significantly different among collection dates within a fruit species. ${ }^{\S}$ Means followed by different upper case letter are significantly different among host fruits in each collection date.
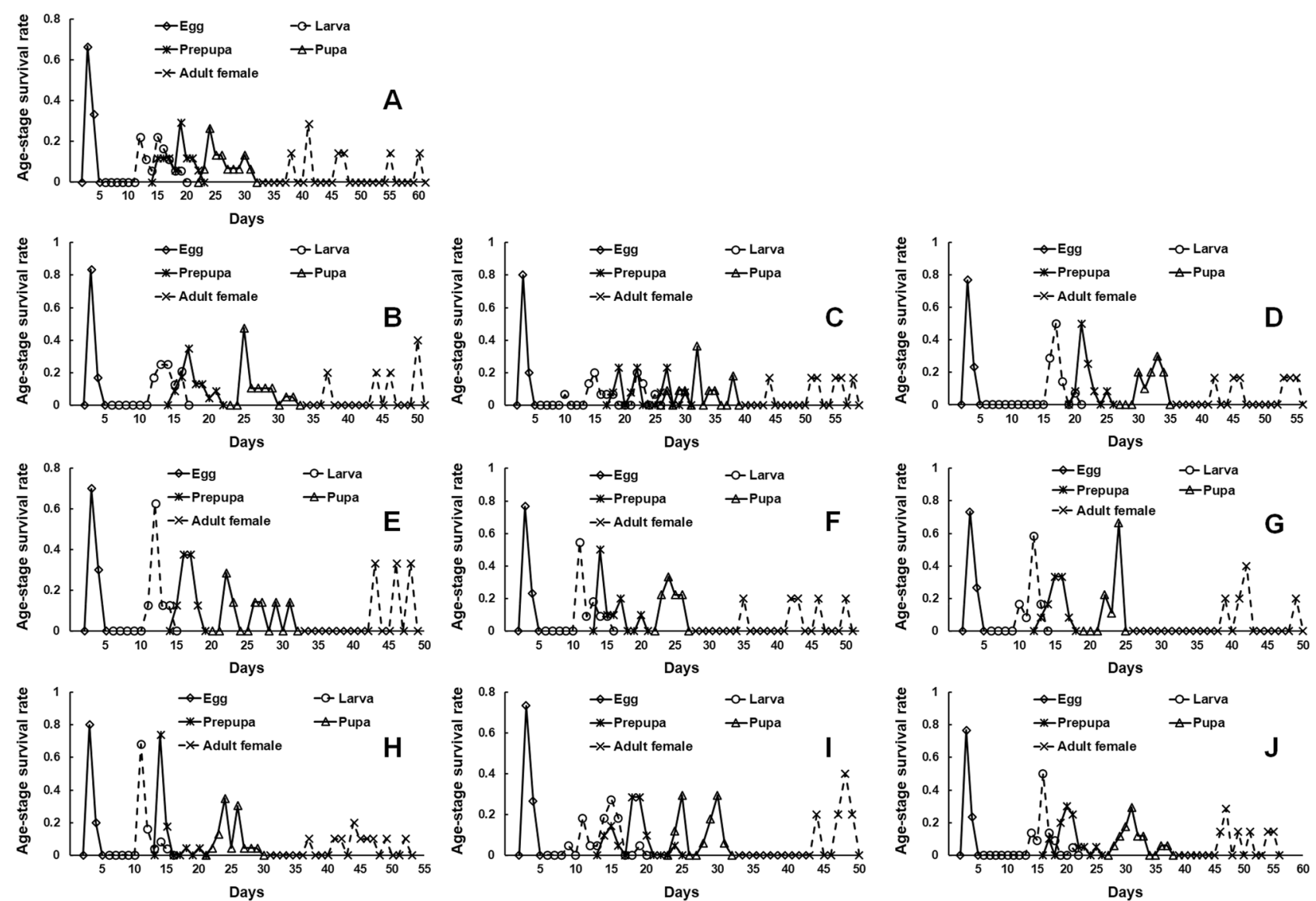

Figure 1. Age-stage survival rate $\left(S_{x j}\right)$ of Grapholita molesta in plum collected on (A) May 11, (B) May 31, (C) June 11, and (D) June 25; peach collected on (E) May 31, (F) June 11, and (G) June 25; and apple collected on (H) May 31, (I) June 11 and (J) June 25.

Age- and stage-specific survival rates of G. molesta larvae were highest on 11th day in both peach and apple collected on May 31 (Fig. 1). The peaks of larval survival rate became extended as fruit collection dates in plum and apple. But, the peaks of larval survival rate appeared between 10 and 15 th day in peach.

Longevity and fecundity of adult females. Preoviposition period and fecundity of $G$. molesta were significantly affected by fruit species (preoviposition period $F=6.84, d f=2,27, P=0.004$; fecundity $F=30.21, d f=2$, $27, P<0.001$ ), by collection date (preoviposition period $F=3.21, d f=2,27, P=0.065$; fecundity $F=4.25, d f=2,27$, 


\begin{tabular}{|l|l|l|l|l|l|}
\hline Fruit & Collected on & Preoviposition period (d) & Oviposition period (d) & Fecundity & Longevity (d) \\
\hline \multirow{4}{*}{ Plum } & May $11^{\ddagger}$ & $3.60 \pm 0.24 \mathrm{~b}^{\S}$ & $18.00 \pm 2.43$ & $135.00 \pm 16.43 \mathrm{~b}$ & $21.60 \pm 2.46$ \\
\cline { 2 - 6 } & May 31 & $3.25 \pm 0.25 \mathrm{bB}$ & $18.00 \pm 1.47$ & $205.75 \pm 27.21 \mathrm{aAB}$ & $21.25 \pm 1.44$ \\
\cline { 2 - 6 } & June 11 & $3.60 \pm 0.24 \mathrm{bA}$ & $17.40 \pm 0.68$ & $144.00 \pm 14.60 \mathrm{abC}$ & $21.00 \pm 0.76$ \\
\cline { 2 - 6 } & June 25 & $4.67 \pm 0.33 \mathrm{aA}$ & $16.33 \pm 0.33$ & $150.67 \pm 14.81 \mathrm{abB}$ & $21.00 \pm 0.58$ \\
\hline \multirow{3}{*}{ Peach } & May 31 & $5.33 \pm 0.33 \mathrm{aA}$ & $13.67 \pm 1.45$ & $116.33 \pm 15.59 \mathrm{cB}$ & $19.00 \pm 1.15$ \\
\cline { 2 - 6 } & June 11 & $3.25 \pm 0.25 \mathrm{bA}$ & $17.50 \pm 1.55$ & $202.00 \pm 14.46 \mathrm{bB}$ & $20.75 \pm 1.80$ \\
\cline { 2 - 6 } & June 25 & $3.75 \pm 0.48 \mathrm{bAB}$ & $16.75 \pm 1.11$ & $258.25 \pm 7.60 \mathrm{aA}$ & $20.50 \pm 0.50$ \\
\hline \multirow{3}{*}{ Apple } & May 31 & $3.20 \pm 0.20 \mathrm{aB}$ & $19.20 \pm 1.66$ & $273.40 \pm 20.70 \mathrm{aA}$ & $22.40 \pm 0.78$ \\
\cline { 2 - 6 } & June 11 & $3.33 \pm 0.33 \mathrm{aA}$ & $16.33 \pm 0.33$ & $287.00 \pm 19.22 \mathrm{aA}$ & $19.67 \pm 0.33$ \\
\cline { 2 - 6 } & June 25 & $3.20 \pm 0.20 \mathrm{aB}$ & $18.60 \pm 1.36$ & $281.80 \pm 16.81 \mathrm{aA}$ & $21.80 \pm 1.50$ \\
\hline
\end{tabular}

Table 3. Fecundity of female of Grapholita molesta moths reared as larvae on different fruits under laboratory conditions. ${ }^{\ddagger}$ Excluded in two-way ANOVA. ${ }^{\S}$ Means followed by different lower case letter are significantly different among collection dates within a fruit species. ${ }^{\$ \varsigma}$ Means followed by different upper case letter are significantly different among host fruits in each collection date.

$P=0.024$ ), or by fruit species by collection date interaction (preoviposition period $F=7.44, d f=4,27, P<0.001$; fecundity $F=7.45, d f=4,27, P<0.001$ ) (Table 3 ).

The preoviposition period within plum fruits was longer on June 25 (4.67 d) compared to those collected earlier. But, preoviposition period was longer on May 31 than later dates in peach while it was similar among all collection dates in apple.

Among fruit species, the highest fecundity was found for moths reared as larvae in peach (258.25) and apple (281.80) collected on June 25 . Within each fruit species, fecundity was highest (205.75) in moths reared as larvae in plums collected on May 31, compared to those from fruit collected earlier. Interestingly, in peach fruit, fecundity gradually increased with fruit age and was greatest in fruits collected on June 25. Apple on all dates showed higher fecundity.

However, oviposition period and adult longevity were not affected by fruit species (oviposition period $F=1.93$, $d f=2,27, P=0.164$; longevity $F=0.67, d f=2,27, P=0.522$ ), by collection date (oviposition period $F=0.04, d f=2$, $27, P=0.964$; longevity $F=0.18, d f=2,27, P=0.840$ ), or by fruit species by collection date interaction (oviposition period $F=1.75, d f=4,27, P=0.167$; longevity $F=0.61, d f=4,27, P=0.662)$. Peach fruits collected on June 25 or apple fruits (irrespective of collection date) were the best food sources for G. molesta larvae.

Fruit firmness. Firmness of the fruit surface was influenced by fruit species $(F=214.60, d f=2,73, P<0.001)$, by collection date $(F=44.01, d f=2,73, P<0.001)$, or by fruit species by collection date interaction $(F=4.61$, $d f=4,73, P=0.002$ ) (Fig. 2). For all fruits, fruit firmness gradually decreased over time. Plum fruits collected on May 11 showed highest firmness $(13.30 \mathrm{~N})$, then firmness decreased quickly as collection date. Among all fruit species, the fruit firmness was greater in peach when collected on May $31(11.37 \mathrm{~N})$ or June $11(11.34 \mathrm{~N})$ compared to that for plum or apple.

Fruit sucrose content. Sugar content was also greatly affected by fruit species $(F=211.45, d f=2$, $78, P<0.001)$, by collection date $(F=60.77, d f=2,78, P<0.001)$, or by fruit species by collection date interaction $(F=6.62, d f=4,78, P<0.001)$ (Fig. 2). Sugar content in plum and apple increased with collection date. The sugar content in all fruits was highest on June 25 than those collected on May 31. Among all fruit species and stages, sugar content was highest in peach and apple collected on June 25.

Pupal weights of larvae reared on different fruits. Pupal weights of $G$. molesta were affected by fruit species $(F=15.64, d f=2,125, P<0.001)$, by collection date $(F=5.51, d f=2,125, P=0.005)$, or by fruit by collection date interaction $(F=10.57, d f=4,125, P<0.001)$ (Fig. 2). The highest pupal weight $(13.50 \mathrm{mg})$ was found in peach collected on June 25 and apple for all collection dates. In peach, pupal weight increased with fruit age (=collection date), but did not increase in plum or apple with increased fruit age.

Effect of firmness and sugar content on larval duration, pupal weight, and fecundity. A significant regression was found between firmness and pupal weight in peach $\left(y=-1.32 x+26.34 ; R^{2}=0.214\right.$; $F=6.80, d f=1,25, P=0.015)$, firmness and fecundity in peach $\left(\mathrm{y}=-58.59 \mathrm{x}+830.05 ; \mathrm{R}^{2}=0.576 ; F=12.25, d f=1\right.$, $9, P=0.007)$, firmness and larval duration in plum $\left(\mathrm{y}=-0.37 \mathrm{x}+15.73 ; \mathrm{R}^{2}=0.112 ; F=8.74, d f=1,69, P=0.004\right)$, and firmness and larval duration in apple $\left(\mathrm{y}=-4.42 \mathrm{x}+43.18 ; \mathrm{R}^{2}=0.554 ; F=83.23, d f=1,67, P<0.001\right)$. No relationship was found between firmness and pupal weight or fecundity in both plum and apple or between firmness and larval duration in peach.

Significant regression was found between sugar content and pupal weight in plum $(\mathrm{y}=-1.82 \mathrm{x}+25.31$; $\left.\mathrm{R}^{2}=0.078 ; F=4.91, d f=1,58, P=0.031\right)$, sugar content and pupal weight in peach $\left(\mathrm{y}=3.37 \mathrm{x}-21.80 ; \mathrm{R}^{2}=0.335\right.$; $F=12.61, d f=1,25, P=0.002)$, sugar content and fecundity in peach $\left(\mathrm{y}=148.52 \mathrm{x}-1301.14 ; \mathrm{R}^{2}=0.844 ; F=48.72\right.$, $d f=1,9, P<0.001)$, sugar content and larval duration in plum $\left(\mathrm{y}=4.66 \mathrm{x}-23.08 ; \mathrm{R}^{2}=0.263 ; F=24.60, d f=1\right.$, 

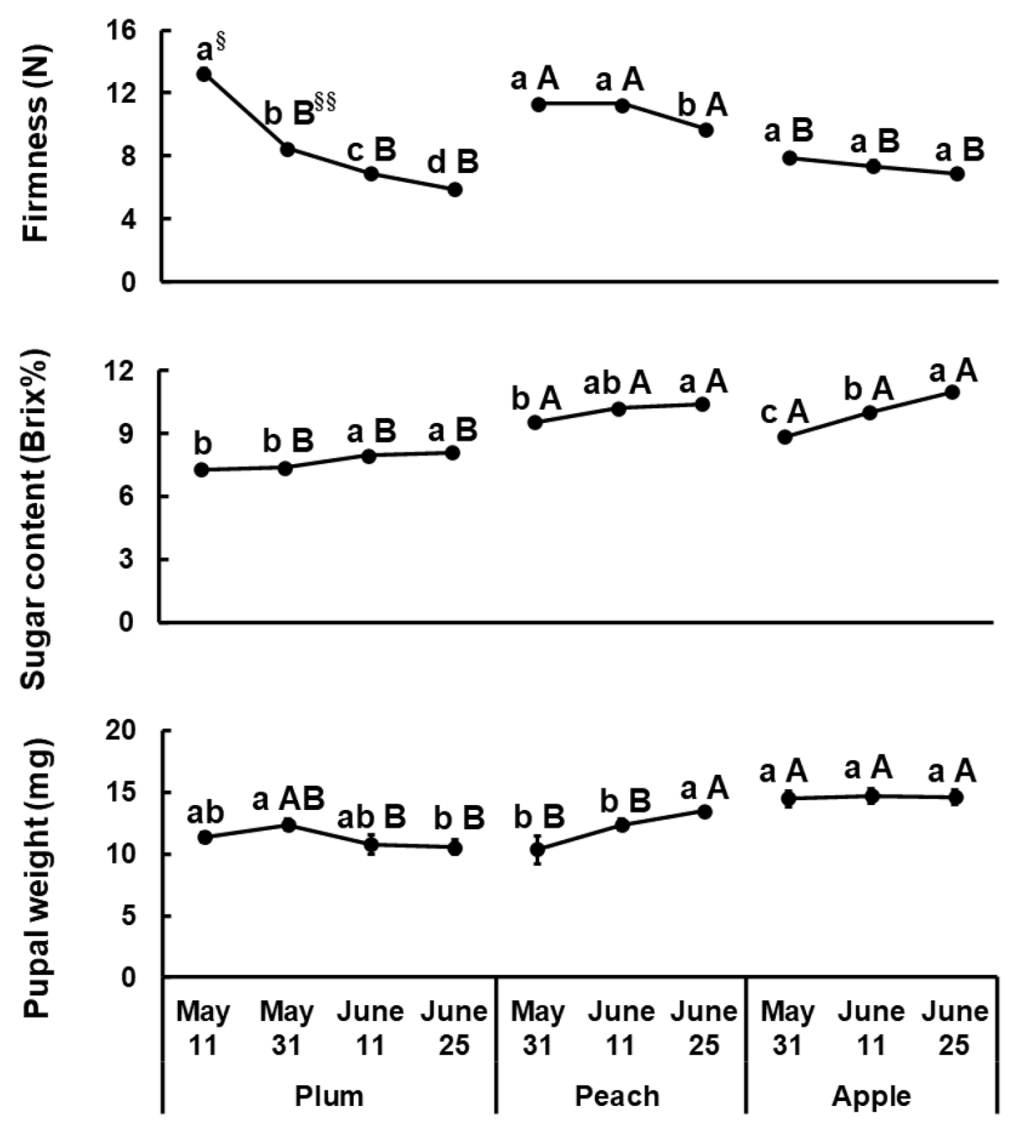

Figure 2. Fruit hardness and sugar content of fruits, compared to pupal weights of Grapholita molesta on rearing fruit. Means followed by different lower case $\left({ }^{\S}\right)$ letter are significantly different among collection dates within a fruit species and different upper case letter $\left({ }^{(\mathfrak{S}}\right)$ are significantly different among host fruits in each collect date.

69, $P<0.001)$, and sugar content and larval duration in apple $\left(\mathrm{y}=1.99 \mathrm{x}-9.21 ; \mathrm{R}^{2}=0.554 ; F=83.11, d f=1,67\right.$, $P<0.001)$.

Fruit effect on life history parameters. Significant differences were observed among fruit species and stages in doubling time $(D T)$, finite rate of increase $(\lambda)$, intrinsic rate of increase $\left(r_{m}\right)$, net reproductive rate $\left(R_{O}\right)$, and mean generation time $(T)$ (Table 4). Doubling time in plums collected on June 25 was higher than that obtained on May 11 or May 31. In contrast, doubling times of larvae reared on peach fruits were lower on June 25 than May 31. Among fruit species, doubling time was higher in plum than in peach or apple collected on June 25.

The finite rate of increase $(\lambda)$ and the intrinsic rate of increase $\left(r_{m}\right)$ for larvae reared on plum was lower on fruits collected June 25 than May 11 or May 31. On the other hand, the finite rate of increase $(\lambda)$ and intrinsic rate of increase $\left(r_{m}\right)$ were higher in peach collected on June 25 compared to those fruits collected on May 31. The net reproductive rate $\left(R_{O}\right)$ was highest on May 31 than later collection date within apple. Among fruit species, net reproductive rate $\left(R_{O}\right)$ was also found highest on May 31 in apple compared to peaches or plums on all collection dates. The mean generation time $(T)$ was shortest in peach collected on June 25 compared to plum or apple collected on the same date. So, from the life table parameters perspective, peaches and apples collected on June 25 and May 31, respectively, were the best food sources for G. molesta.

\section{Discussion}

The availability of host plants is a significant factor determining the population dynamics of herbivorous insects ${ }^{1,13,14}$. The physical characteristics and chemical components of host plants vary with their phenological stages $^{16,17,27-29}$, and this variation affects the performance of herbivorous insects, including development time, survival rate, and fecundity ${ }^{13,30}$. Stone fruits such as peach $(P$. persica), plum $(P$. domestica), and nectarine $(P$. persica var. nectarina) serve as primary hosts for G. molesta, whereas the pome fruits apple (M. domestica) and pear (Pyrus communis L.) are considered secondary hosts ${ }^{2,4}$. Myers et al. ${ }^{22}$ states that larval survival of $G$. molesta is better on ripening peach fruit than immature apple fruit, but they did not show the compounding effect of fruit species and fruit's developmental stage. In our previous study where the suitability of immature fruits were examined $^{26}$, immature apple fruits were found to be better for development of G. molesta than immature peach fruit. Thus, in this study, we further evaluated the effect of developmental characteristics of three kinds of fruits 


\begin{tabular}{|c|c|c|c|c|c|c|}
\hline \multirow[b]{2}{*}{ Fruit } & \multirow[b]{2}{*}{ Collected on } & \multicolumn{5}{|c|}{ Parameters $($ mean \pm SE) } \\
\hline & & $D T$ & $\lambda$ & $r_{m}$ & $R_{O}$ & $T$ (day) \\
\hline \multirow{4}{*}{ Plum } & May 11 & $5.87 \pm 0.27 \mathrm{~b}^{\S}$ & $1.13 \pm 0.01 \mathrm{a}$ & $0.12 \pm 0.01 \mathrm{a}$ & $31.73 \pm 3.86 \mathrm{a}$ & $29.37 \pm 1.16 b$ \\
\hline & May 31 & $5.36 \pm 0.37 \mathrm{bB}^{\S \varsigma}$ & $1.14 \pm 0.01 \mathrm{aB}$ & $0.13 \pm 0.01 \mathrm{aB}$ & $38.89 \pm 5.14 \mathrm{aB}$ & $28.46 \pm 1.30 \mathrm{bA}$ \\
\hline & June 11 & $6.96 \pm 0.34 \mathrm{aB}$ & $1.10 \pm 0.01 \mathrm{bB}$ & $0.10 \pm 0.00 \mathrm{bB}$ & $29.30 \pm 2.97 \mathrm{aB}$ & $34.03 \pm 1.02 \mathrm{aA}$ \\
\hline & June 25 & $7.09 \pm 0.30 \mathrm{aB}$ & $1.10 \pm 0.00 \mathrm{bB}$ & $0.10 \pm 0.00 \mathrm{bB}$ & $29.83 \pm 2.93 \mathrm{aC}$ & $34.84 \pm 0.62 \mathrm{aA}$ \\
\hline \multirow{3}{*}{ Peach } & May 31 & $8.31 \pm 0.38 \mathrm{aA}$ & $1.09 \pm 0.00 \mathrm{bC}$ & $0.08 \pm 0.00 \mathrm{bC}$ & $10.70 \pm 1.43 \mathrm{cC}$ & $28.53 \pm 1.90 \mathrm{aA}$ \\
\hline & June 11 & $5.22 \pm 0.08 \mathrm{bA}$ & $1.14 \pm 0.00 \mathrm{aA}$ & $0.13 \pm 0.00 \mathrm{aA}$ & $33.94 \pm 2.43 \mathrm{bB}$ & $26.58 \pm 0.86 \mathrm{aB}$ \\
\hline & June 25 & $4.73 \pm 0.21 \mathrm{bA}$ & $1.16 \pm 0.01 \mathrm{aA}$ & $0.15 \pm 0.01 \mathrm{aA}$ & $43.39 \pm 1.28 \mathrm{aB}$ & $25.72 \pm 1.13 \mathrm{aC}$ \\
\hline \multirow{3}{*}{ Apple } & May 31 & $4.22 \pm 0.14 \mathrm{bC}$ & $1.18 \pm 0.01 \mathrm{aA}$ & $0.16 \pm 0.01 \mathrm{aA}$ & $90.52 \pm 6.85 \mathrm{aA}$ & $27.44 \pm 1.15 \mathrm{aA}$ \\
\hline & June 11 & $5.20 \pm 0.19 \mathrm{aA}$ & $1.14 \pm 0.01 \mathrm{bA}$ & $0.13 \pm 0.00 \mathrm{bA}$ & $47.44 \pm 3.18 \mathrm{cA}$ & $28.95 \pm 1.32 \mathrm{aB}$ \\
\hline & \begin{tabular}{|l|} 
June 25 \\
\end{tabular} & $5.04 \pm 0.18 \mathrm{aA}$ & $1.15 \pm 0.01 \mathrm{bA}$ & $0.14 \pm 0.00 \mathrm{bA}$ & $65.86 \pm 3.93 \mathrm{bA}$ & $30.46 \pm 0.82 \mathrm{aB}$ \\
\hline
\end{tabular}

Table 4. Life table parameters of Grapholita molesta reared as larvae on different fruits. Student's $t$ test was conducted for pairwise group comparison at $P<0.05$. DT doubling time, $\lambda$ finite rate of increase, $r_{m}$ intrinsic rate of increase, $R_{O}$ net reproductive rate, $T$ mean generation time. ${ }^{\S}$ Means followed by different lower case letter are significantly different among collection dates within a fruit species. ${ }^{\S \S}$ Means followed by different upper case letter are significantly different among host fruits in each collection date.

on the development and fecundity performance of $G$. molesta along with an examination of firmness and sugar content of the fruits.

We found that fruit species and fruit developmental stage both significantly affected the larval development, reproduction, and life table parameters of $G$. molesta, although the duration of the egg stage of G. molesta was not affected, findings that are similar to Sarker and $\mathrm{Lim}^{26}$ and $\mathrm{Du}$ et al. ${ }^{1}$. The duration of the larval stage was shortest in peach fruits on June 11 and June 25 compared to all plum or apple fruits collected on the same dates. Myers et al. ${ }^{21}$ and Najar-Rodriguez et al. ${ }^{3}$ also found that larvae of G. molesta developed faster in peach than in apple. The larval-pupal duration was also shorter in peach collected on June than in plum or apple collected in the same period. Similarly, Du et al. ${ }^{1}$ found that the immature period of G. molesta was shorter in peach than in pear, which might be caused by the relatively high sugar content of peaches. Nevertheless, fruit quality could directly affect such development of G. molesta in various ways including physical condition, nutrition, and phenolic compound $s^{31,32}$. Larval duration increased with fruit maturity (i.e., collection date) in plum and apple, similar to another study by Du et al. ${ }^{1}$ in which larval duration of G. molesta became longer in pear fruit collected in the late season compared to in fruits collected the early season.

The fruit penetration rate of first instars was greatly affected by the firmness of the fruits and was lowest in peach with the highest firmness compared to plum and apple, all collected on May 31. However, plum fruits collected on May 11 were firmer than the peach collected on May 31 but showed a higher entering rate compared to the peach. Thus, firmness might not be the only cause for the failure on the part of G. molesta to enter fruits. According to previous studies, the long and dense hair of peach fruits make larval penetration more difficult ${ }^{33,34}$. Reduction in pubescence results in higher fecundity for Cydia pomonella (L.) in peach fruits ${ }^{35,36}$. Westgard et al. ${ }^{37}$ and Plourde et al. ${ }^{38}$ also demonstrated that pubescence is related with deterrence of C. pomonella. Therefore, in peach, the fruit penetration rate might be similarly low in all developmental periods regardless of firmness even though reproduction and development was better for those larvae in the fruit. This might be the reason for the relatively low total survival rate found in peach, and similarly, Du et al. ${ }^{1}$ found that preimaginal survival rate of G. molesta was $30 \%$ in peach fruit collected on June 25 . This explanation is supported by the life table analysis where we found the highest $r_{m}$ value and pupal weight in peach fruit collected on June 25 .

The preoviposition period of $G$. molesta females was longest on late-collected plum and early-collected peach. The fecundity and pupal weight were also lowest on late-collected plum and early-collected peach. Similarly, Sarker and $\mathrm{Lim}^{26}$ found that the preoviposition period of G. molesta in peach was greater on fruits collected on May 25 compared to plum or apple collected at the same time. Du et al. ${ }^{1}$ also found that both parameters, preoviposition period and pupal weight, were poor on late season pear. Late-collected plums may not be a good food source because it liquefies quickly. Poor food quality typically results in lower growth rates, smaller body sizes, and reduced fecundity ${ }^{39,40}$. The preoviposition period may be negatively correlated with pupal weight, as numerous studies reported that pupal weight is positively correlated with fecundity, and both pupal weight and fecundity of lepidopteran pests are influenced by host plants $\mathrm{s}^{3,41-44}$

In plum, we found better development, reproduction, and intrinsic rate of increase $\left(r_{m}\right)$ in fruit collected early except fruits collected on May 11 which show much higher firmness. However, plum fruits collected late had very low firmness, and thus were not suitable especially for the development of G. molesta. In contrast, development, reproduction, and intrinsic rate of increase $\left(r_{m}\right)$ were better in the late-collected peach fruit which had a higher firmness and higher sugar content than plum. According to Van Steenwyk et al. ${ }^{17}$, as pear fruits grow, stone cells break down in late June to mid-July, and the fruits become more suitable for infestation and development for $C$. pomonella. However, by late July through mid-August, the larvae less likely to complete development because the pears are starting to rot and liquefy faster. This may be a similar reason to why plum fruits collected on June 25 were less suitable even though sugar content was higher. The firmness of apple fruits collected on June 25 was similar to plum collected on June 11, but the sugar content of the apple was higher than the plum. Firmness 
and sugar content are essential for larval development and reproduction ${ }^{17,45}$. This study will help to establish the firmness and sugar content of fruits required for the development and reproduction of G. molesta.

Understanding the relationship between the life history parameters of an insect and developmental periods of host plants improves the accuracy of forecasting population dynamics and contributes to the practical application of integrated pest management programs. Both firmness and sugar content are important factors for the development and reproduction of G. molesta. In general, peach was better for the development of G. molesta as it has a higher sugar content, but it showed a lower penetration rate and survival rate, irrespective of fruit developmental period. Plum, while showing a higher larval penetration rate, were generally unsuitable for development and reproduction due to its rapid liquefaction. In apple, highest levels of fruit penetration, moth reproduction, and overall $r_{m}$ were observed, probably due to apple having proper firmness and higher sugar content. Thus, for development and reproduction, apple fruit would be the best food source for G. molesta. However, further studies are needed to assess the effects of other components such as proteins and lipids of those fruit on the life table parameters of G. molesta.

\section{Methods}

Insect rearing. Larvae of G. molesta were reared in apples fruit described by Sarker and $\mathrm{Lim}^{46}$. Apples infested with oriental fruit moth larvae were collected and kept in a growth chamber (DS-11BPL, Dasol Scientific Co. Ltd, Hwaseong, Republic of Korea) at $24.92 \pm 0.11^{\circ} \mathrm{C}, 50.21 \pm 1.33 \% \mathrm{RH}$, and a 16:8 h (L:D) photoperiod. When the larvae reached the fifth instar, they emerged from the apples and spun cocoons in the paper towel provided for pupation. Pupae were collected from paper towel and placed in breeding dishes $(10.0 \mathrm{D} \times 4.0 \mathrm{H}$ $\mathrm{cm}, 310102$, SPL, Pocheon, Republic of Korea). After the emergence of adult moths, they were moved into ventilated acrylic cylinders $(25.5 \mathrm{H} \times 8.5 \mathrm{D} \mathrm{cm})$ and provided with a piece of cotton soaked in $10 \%$ sugar solution as a food source. The acrylic cylinders were held in a desiccator $(36.0 \mathrm{~L} \times 28.0 \mathrm{~W} \times 25.0 \mathrm{H} \mathrm{cm})$ and incubated at $25.63 \pm 0.14{ }^{\circ} \mathrm{C}$ and $91.22 \pm 0.12 \% \mathrm{RH}$. Once moths had begun laying eggs on the cylinder walls, cages were changed daily to obtain age-specific cohorts of eggs. In a separate incubator, acrylic cylinders with eggs on the walls were kept before the egg hatch, and the first instar larvae were collected for life table experiments or further mass rearing. For our experiments, we reared G. molesta for eight generations, and, to minimize inbreeding depression, wild males were added to the rearing population periodically.

Plant materials. In this study, three kinds of fruits (plum, peach, and apple) were used. Fruits of plum ( $P$. domestica variety "Royal Daeseok), peach [P. persica locally collected unknown variety), and apple (M. domestica variety "Fuji," strain 'Busa') were collected from Iljeek, Dosan, and Gilan Counties, respectively, near Andong, Republic of Korea, in 2017. Plum fruits were collected at four developmental stages (on May 11, May 31, June 11, and June 25), and peach and apple fruits were collected on three developmental stages (on May 31, June 11, and June 25) in 2017. All the orchards were free of pesticide use. The approximate dates of bloom for plum, peach, and apple are mid March-mid April, early April-mid April, and April, respectively. The dates of fruit setting for plum, peach, and apple are mid April-late April, April-May, and April-May, respectively. The harvest time for plum, peach, and apple are mid June-August, July-October, and late October-early November ${ }^{47}$. The diameter of all fruits used in the life table study were $1.77 \pm 0.04,2.67 \pm 0.03,4.06 \pm 0.07$, and $4.38 \pm 0.05 \mathrm{~cm}$ when the plum fruits were collected on May 11, May 31, June 11, and June 25; $2.34 \pm 0.03,3.09 \pm 0.10$, and $3.71 \pm 0.05 \mathrm{~cm}$ for peach fruits collected on May 31, June 11, and June 25; and 3.40 $\pm 0.06,3.80 \pm 0.33$, and $4.00 \pm 0.04$ for apple fruit collected on these same dates, respectively. After washing fruits with warm water, they were sealed in plastic ziplock bags and held at $4{ }^{\circ} \mathrm{C}$ in a refrigerator before being used in the assays within 2 days.

Stage development and survival. In this experiment, field-collected fruits were placed in a breeding dish $(10.0 \mathrm{D} \times 4.0 \mathrm{H}, 310102$, SPL, Pocheon, Republic of Korea), and one G. molesta larva (<6 h old) was released on each fruit and held at $24.85 \pm 0.10^{\circ} \mathrm{C}, 43.74 \pm 0.61 \% \mathrm{RH}$, and a $16: 8 \mathrm{~h}(\mathrm{~L}: \mathrm{D})$ photoperiod in the incubator. Thirty larvae were used in each treatment. Once a mature larva emerged from a fruit, it was transferred for pupation into another breeding dish filled with tissue papers. The duration of the larval stage was measured as the time from egg hatch to the exit of the mature larva from the fruit; the duration of the prepupal stage was defined as the period from the exit of the mature larva from the fruit to the pupation; and the duration of the pupal stage was from the pupation to the adult emergence.

Longevity and fecundity of adult females. When adults emerged, they were transferred to transparent square breeding dishes $(7.2 \mathrm{~L} \times 7.2 \mathrm{~W} \times 10.0 \mathrm{H} \mathrm{cm} \mathrm{SPL}$, Pocheon, Republic of Korea, each with three $40 \mathrm{~mm}$ mesh screens; one per side) and held with one male and one female moth per dish. To provide a carbohydrate source, a cotton wick soaked in $10 \%$ sugar solution was placed in each container. Freshly laid eggs on the surface of the container were marked and recorded daily until the adult female died. To avoid pathogenic infections, breeding dishes were replaced daily with new ones. An absence of spermatophores was used to indicate an unmated female, and these moths were excluded from the analysis ${ }^{1}$.

Measurement of firmness of fruit surface. Fruit firmness was measured with a texture analyzer (EZTest/ CE-346-51990, Shimadzu Corporation, Nakagyo, Kyoto, Japan), which determined the penetration force needed to press a plunger into the fruit. Firmness is the maximum test force loaded on the fruits before penetration, and readings were in Newtons $(\mathrm{N})$. Firmness was measured for each of ten randomly selected fruits in each developmental stage of each species. 
Measurement of sucrose content in fruit. A refractometer (HI 96801 Refractometer, Hanna Instruments Inc., Woonsocket, Rhode Island), was used to determine sucrose levels of fruits by measuring the refractive index to determine the \% Brix of sugar in an aqueous solution (where one degree Brix equals $1 \mathrm{~g}$ of sucrose in $100 \mathrm{~g}$ of solution). To get aqueous solution, fruit parts (exocarp or mesocarp) were placed in a $2 \mathrm{~mL}$ microtube (14217394, Axygen, Corning, NY) and a tissue grinder was used to crush the fruit parts. A plastic pipette was then used to collect a sample of this solution and place it onto the prism surface of the refractometer. Ten randomly selected fruits were used for such measurements at each developmental stage of each species, with three replicates of each type (exocarp and mesocarp). These three samples were collected from different positions on each sample fruit and averaged within fruits.

Statistical analysis. To analyze the effect of fruit species and fruit stage on egg duration, oviposition period, preoviposition period, fecundity, the firmness of fruit surface, and sucrose content of fruits, two-way ANOVA was conducted by using PROC GLM in SAS ${ }^{48}$ after checking for normality and homogeneity using a Kolmogorov-Smirnov test and a Levene test, respectively. In the case of data with heterogeneity (duration of larva, prepupa, pupa, and larva-pupa stage, longevity, and pupal weight), Friedman's two-way non-parametric ANOVA was conducted using SAS 9.44. Data of plum on May 11 were excluded from the two-way ANOVA analysis. After that, one-way parametric or non-parametric ANOVA (weighted least squares method) was performed for the multiple comparison (Bonferroni $t$ test) within fruit species on different collection date and among fruit species on each collection date using SAS $9.4^{48}$.

Similarly, hatching rates of eggs, fruit penetration rates of first instars, fruit exiting rates of mature larva, larval survival rates, pupation rates, emergence rates, and total immature survival rates were analyzed with Friedman's two-way ANOVA. Data of plum on May 11 were excluded from the analysis. For the multiple comparison within fruit species on different collection date and among fruit species on each collection date, chi-square tests with a post-hoc multiple comparison analogous to Tukey's test ${ }^{49}$ were used.

Larval duration, pupal weight, and fecundity were regressed against fruit firmness or sugar content using SAS $9.4^{48}$.

The jackknife procedure was performed to test the differences within fruit species on different collection date and among fruit species on each collection date in population parameters, i.e., doubling time $(D T)$, finite rate of increase $(\lambda)$, intrinsic rate of increase $\left(r_{m}\right)$, net production rate $\left(R_{O}\right)$, and mean generation time of $(T)^{50}$. The survival rate $\left(S_{x j}\right)(x=$ age, $j=$ stage $)$ is the probability that a newly laid egg would survive to age $x$ and stage $j$. Jackknife algorithms for estimating the means and variances and constructing confidence intervals were described only for $R_{O}$ (the net contribution of each female to the next generation, expressed as the total female offspring per female over the whole oviposition period $)^{50}$. The same procedures were used to estimate other parameters $\left(r_{m}, T, D T\right.$, and $\left.\lambda\right)$. All fertility data in the life tables were entered in a computer program (LIFETABLE.SAS) ${ }^{50}$ and analyzed using SAS $9.4^{48}$.

Ethics statement. This research work is the authors' own original work, which has not been previously published elsewhere. The paper is not currently being considered for publication elsewhere. The paper reflects the authors' own research and analysis in a truthful and complete manner.

Received: 8 October 2020; Accepted: 4 January 2021

Published online: 22 January 2021

\section{References}

1. Du, J. et al. Development and fecundity performance of oriental fruit moth (Lepidoptera: Tortricidae) reared on shoots and fruits of peach and pear in different seasons. Environ. Entomol. 44, 1522-1530 (2015).

2. Rothschild, G. H. L. \& Vickers, R. A. Biology, ecology and control of the oriental fruit moth. In Tortricid Pests: Their Biology, Natural Enemies and Control (eds van der Geest, L. P. S. \& Evenhuis, H. H.) 389-412 (Elsevier, New York, 1991).

3. Najar-Rodriguez, A. et al. Larval performance of the oriental fruit moth across fruits from primary and secondary hosts. Physiol. Entomol. 38, 63-70 (2013).

4. Rice, R. E. et al. Pear as a host of the oriental fruit moth in California. J. Econ. Entomol. 65, 1212-1213 (1972).

5. Zhao, Z. R. et al. A preliminary report on the oriental fruit moth in north Jiangsu. Insect Knowl. 26, 17-19 (1989).

6. Zhang, X. Z. A preliminary report on the study of oriental fruit moth. Acta Phytophys. Sin. 7, 254-256 (1980).

7. Kanga, L. H. B. et al. Monitoring for resistance to organophosphorus, carbamate, and pyrethroid insecticides in the oriental fruit moth (Lepidoptera: Tortricidae). Can. Entomol. 131, 441-450 (1999).

8. Kovanci, O. \& Walgenbach, J. Monitoring the oriental fruit moth with pheromone and bait traps in apple orchards under different management regimes. Int. J. Pest Manag. 24, 273-279 (2005).

9. Piñero, J. C. \& Dorn, S. Synergism between aromatic compounds and green leaf volatiles derived from the host plant underlies female attraction in the oriental fruit moth. Entomol. Exp. Appl. 125, 185-194 (2007).

10. Ahn, J. J. et al. Model of Grapholita molesta spring emergence in pear orchards based on statistical information criteria. J. Asia Pac. Entomol. 15, 589-593 (2012).

11. Walter, A. J. et al. Acceptance and suitability of novel trees for Orthotomicus erosus, an exotic bark beetle in North America. Biol. Invas. 12, 1133-1144 (2010).

12. Zhang, W. et al. Dietary flexibility aids Asian earthworm invasion in North American forests. Ecology 91, 2070-2079 (2010).

13. Ishihara, M. \& Ohgushi, T. Reproductive inactivity and prolonged developmental time induced by seasonal decline in host plant quality in the willow leaf beetle Plagiodera versicolora (Coleoptera: Chrysomelidae). Environ. Entomol. 35, 524-530 (2006).

14. Naseri, B. et al. Comparative life history and fecundity of Helicoverpa armigera (Hubner) (Lepidoptera: Noctuidae) on different soybean varieties. Entomol. Sci. 12, 147-154 (2009).

15. Riedl, T. L. H. et al. A century of codling moth control in South Africa: II. Current and future status of codling moth management. J. South Afr. Soc. Hortic. Sci. 8, 32-54 (1998).

16. Bezemer, T. M. \& Mills, N. J. Walnut development affects chemical composition and codling moth performance. Agric. For. Entomol. 3, 191-199 (2001). 
17. Van Steenwyk, R. A. et al. Seasonal susceptibility of 'Bartlett' pears to codling moth (Lepidoptera: Tortricidae) infestation and notes on diapause induction. J. Econ. Entomol. 97, 976-980 (2004).

18. Nielsen, A. L. et al. Seasonal phenology and monitoring of the non-native Halyomorpha halys (Hemiptera: Pentatomidae) in soybean. Environ. Entomol. 40, 231-238 (2011).

19. Onstad, D. W. et al. Influence of apple cultivar, tree phenology, and leaf quality on the development and mortality of Choristoneura rosaceana (Lepidoptera: Tortricidae). Can. Entomol. 118, 123-132 (1986).

20. Lawrence, R. K. et al. White spruce and the spruce budworm: Defining the phenological window of susceptibility. Can. Entomol. 129, 291-318 (1997).

21. Myers, C. T. et al. Effects of orchard host plants (apple and peach) on development of oriental fruit moth (Lepidoptera: Tortricidae). J. Econ. Entomol. 100, 421-430 (2007).

22. Myers, C. T. Comparative survival rates of oriental fruit moth (Lepidoptera: Tortricidae) larvae on shoots and fruit of apple and peach. J. Econ. Entomol. 99, 1299-1309 (2006).

23. Piñero, J. C. \& Dorn, S. Response of female oriental fruit moth to volatiles from apple and peach trees at three phonological stages. Entomol. Exp. Appl. 131, 67-74 (2009).

24. Lu, P. F. et al. Identification and field evaluation of pear fruit volatiles attractive to the oriental fruit moth, Cydia molesta. J. Chem. Ecol. 38, 1003-1016 (2012).

25. Hopkins, R. J. et al. Relationships between turnip root fly (Delia floralis) larval development and the sugar content of swede (Brassica napus ssp. rapifera) roots. Ann. Appl. Biol. 122, 405-415 (1993).

26. Sarker, S. \& Lim, U. T. Development and fecundity performance of Grapholita molesta and Grapholita dimorpha (Lepidoptera: Tortricidae) on different immature fruits. PLoS One 14, e0217492 (2019).

27. Mattson, W. J. Herbivory in relation to plant nitrogen content. Annu. Rev. Ecol. Syst. 11, 119-161 (1980).

28. Drossopoulos, J. B. et al. Seasonal dynamics of mineral nutrients by walnut tree fruits. J. Plant Nutr. 19, 435-455 (1996).

29. Hartley, S. E. \& Jones, C. G. Plant chemistry and herbivory or why the world is green. In Plant Ecology (ed. Crawley, M. J.) 284-324 (Blackwell Science, Oxford, 1997).

30. Awmack, C. S. \& Leather, S. R. Host plant quality and fecundity in herbivorous insects. Annu. Rev. Entomol. 47, 817-844 (2002).

31. Kim, D. S. \& Lee, J. H. Egg and larva survivorship of Carposina sasakii (Lepidoptera: Carposinidae) in apple and peach and their effects on adult population dynamics in orchards. Environ. Entomol. 31, 686-692 (2002).

32. Guerra, D. J. et al. Influence of selected phenolic compounds on development of bollworm (Lepidoptera: Noctuidae) larvae. J. Econ. Entomol. 83, 2115-2118 (1990).

33. Liu, Y. et al. Study on correlation among stone cell content, PAL activity and fruit hardness. Xinjiang Agric. Sci. 48, 1597-1601 (2011).

34. Lei, X. H. et al. Effect of host plants on developmental time and life table parameters of Carposina sasakii (Lepidoptera: Carposinidae) under laboratory conditions. Environ. Entomol. 41, 349-354 (2012).

35. Yokoyama, V. Y. \& Miller, G. T. Laboratory evaluations of codling moth (Lepidoptera: Tortricidae) oviposition on three species of stone fruit grown in California. J. Econ. Entomol. 81, 568-572 (1988).

36. Yokoyama, V. Y. \& Miller, G. T. Laboratory evaluations of oriental fruit moth (Lepidoptera: Tortricidae) oviposition and larval survival on five species of stone fruits. J. Econ. Entomol. 81, 867-872 (1988).

37. Westigard, P. H. et al. Codling moth: Egg and first instar mortality on pear with special reference to varietal susceptibility. Environ. Entomol. 5, 51-54 (1976).

38. Plourde, D. F. et al. Pubescence as a factor in codling moth, oviposition, and fruit entry in five apple selections. HortScience 20, 82-84 (1985).

39. Cressler, C. E. et al. Unexpected nongenetic individual heterogeneity and trait covariance in Daphnia and its consequences for ecological and evolutionary dynamics. Am. Nat. 190, 13-27 (2017).

40. Sterner, R. W. \& Schulz, K. L. Zooplankton nutrition: Recent progress and a reality check. Aquat. Ecol. 32, 261-279 (1998).

41. Cisneros, F. H. \& Barnes, M. M. Contribution to the biological and ecological characterization of apple and walnut host races of codling moth, Laspeyresia pomonella (L): Moth longevity and oviposition capacity. Environ. Entomol. 3, 402-406 (1974).

42. Robison, D. J. et al. Spruce budworm (Lepidoptera: Tortricidae) field fecundity: New insights into its estimation and use. For. Ecol. Manag. 106, 73-81 (1998).

43. Asaro, C. \& Berisford, C. W. Seasonal changes in adult longevity and pupal weight of the Nantucket pine tip moth (Lepidoptera: Tortricidae) with implications for interpreting pheromone trap catch. Environ. Entomol. 30, 999-1005 (2001).

44. Azidah, A. A. \& Sofian-Azirun, M. Fecundity study of Spodoptera Exigua (hübner) (Lepidoptera: Noctuidae) on various host plants. J. Entomol. 3, 261-266 (2006).

45. Güler, P. et al. The effects of larval diet restriction on developmental time, preadult survival, and wing length in Drosophila melanogaster. Turk. J. Zool. 39, 395-403 (2015).

46. Sarker, S. \& Lim, U. T. Extract of Nicotiana tabacum as a potential control agent of Grapholita molesta (Lepidoptera: Tortricidae). PLoS One 13, e0198302 (2018).

47. Research and Development of Agriculture (RDA). http://www.nongsaro.go.kr (2020).

48. Institute, S. A. S. SAS User's Guide: Statistics (SAS Institute, Cary, 2013).

49. Zar, J. H. Biostatistical Analysis 5th edn. (Prentice Hall, Upper Saddle River, 2010).

50. Maia, A. N. et al. Statistical inference on associated fertility life table parameters using jackknife technique: Computational aspects. J. Econ. Entomol. 93, 511-518 (2000).

\section{Acknowledgements}

This work was supported by the Korea Institute of Planning and Evaluation for Technology in Food, Agriculture, Forestry, and Fisheries through the Advanced Production Technology Development Program, funded by the Ministry of Agriculture, Food, and Rural Affairs (315007-03-2).

\section{Author contributions}

S.S. and U.T.L. designed the study including experimental design. S.S. carried out laboratory work. S.S. and U.T.L. analyzed the data and drafted the manuscript. S.S. and U.T.L. contributed to revise the draft. S.S. and Y.H.W. contributed to fruit collection.

\section{Competing interests}

The authors declare no competing interests.

\section{Additional information}

Correspondence and requests for materials should be addressed to U.T.L. 
Reprints and permissions information is available at www.nature.com/reprints.

Publisher's note Springer Nature remains neutral with regard to jurisdictional claims in published maps and institutional affiliations.

(c) (i) Open Access This article is licensed under a Creative Commons Attribution 4.0 International License, which permits use, sharing, adaptation, distribution and reproduction in any medium or format, as long as you give appropriate credit to the original author(s) and the source, provide a link to the Creative Commons licence, and indicate if changes were made. The images or other third party material in this article are included in the article's Creative Commons licence, unless indicated otherwise in a credit line to the material. If material is not included in the article's Creative Commons licence and your intended use is not permitted by statutory regulation or exceeds the permitted use, you will need to obtain permission directly from the copyright holder. To view a copy of this licence, visit http://creativecommons.org/licenses/by/4.0/.

(C) The Author(s) 2021 